\section{WFUMB 2021 Timișoara, România}

Anul 2021 va fi un an important pentru ecografia românească. Pentru 4 zile Capitala Ultrasonografiei Mondiale va fi Timișoara, între 26-29 Mai 2021, perioada de desfășurare a Celui de-al XVIII Congres Mondial de Ultrasonografie - WFUMB 2021 (www. wfumb2021.com), manifestare ce se va desfășura în conjuncție cu alte două evenimente ecografice majore: AI XXXIII-lea Congres al Federației Europene a Societăților de Ultrasonografie în Medicină și Biologie - EFSUMB - EUROSON 2021 și A XXIV-a Conferință Națională a Societății Române de Ultrasonografie în Medicină și Biologie din România.

Este o mare onoare pentru Societatea Română de Ultrasonografie în Medicină și Biologie - SRUMB încredințarea organizării acestei prestigioase manifestări, ce are loc odată la 2 ani. De aceea și pregătirile sunt pe măsură.

Această manifestare de înalt nivel internațional va menține tradiția unui program echilibrat, ce va include o zi de cursuri postuniversitare concentrate pe diverse domenii de interes din ultrasonografie, care vor oferi cele mai noi informații în domeniul ultrasonografiei diagnostice şi intervenționale. Între subiectele cursurilor vor exista: ecografia de sân, ecografia musculoscheletală, ecografia vasculară, ecocardiografie, ecografia în practica medicului de familie etc. Restul programului va cuprinde multiple sesiuni paralele, care vor acoperi diversele aplicații ale ultrasonografiei, sesiuni ce vor cuprinde atât prezentări state-of-art dar și rezultatele cercetărilor în domeniile respective în prezentări originale. Nu vor lipsi sesiunile ce vor aborda cele mai noi domenii ale ultrasonografiei: ecografia cu contrast, elastografia, utilizarea inteligenței artificiale în ultrasonografie.

Manifestarea va beneficia de aportul experților internaționali în diversele domenii ale ecografiei, care vor aborda de la elemente de bază în ultrasonografie la cele mai noi dezvoltări ale acestei tehnici.

În conjuncție cu Congresul Mondial de Ultrasonografie WFUMB 2021 se va desfășura la Timișoara și prima Conferință Mondială de Ultrasonografie pentru Studenți, 28-29 Mai 2021. Această manifestare își dorește să aducă mai aproape de studenți această tehnică imagistică extrem de frumoasă și utilă în practica medicală, indiferent de specialitatea aleasă.

Nu în ultimul rând organizatorii manifestării doresc să aducă în prim plan și ospitalitatea românească, invitând participanții să se bucure de experiența Orașului Florilor Timișoara.

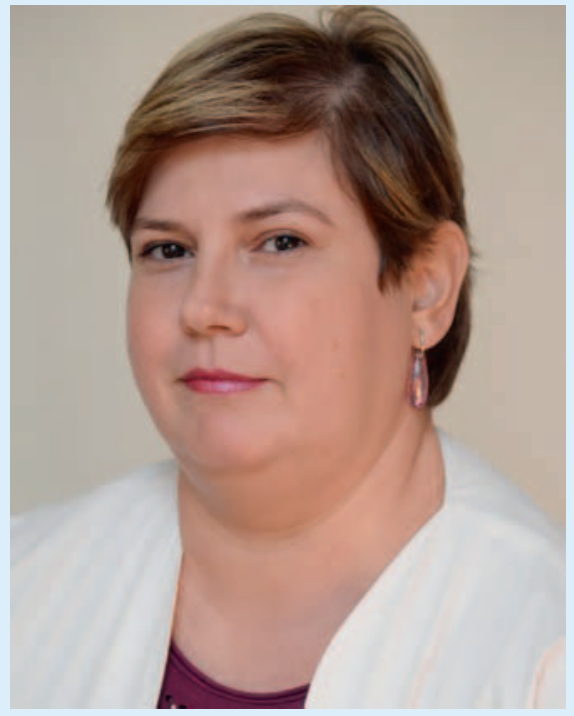

Prof. Dr. Alina Popescu

Toți cei interesați sunt așteptați la WFUMB 2021, și invitați să beneficieze de prețurile speciale mult reduse pentru membrii SRUMB (pentru toți cei ce demonstrează calitatea de membru SRUMB pentru anii 2020 și 2021).

Informații detaliate despre această manifestare găsiți pe websiteul manifestării www.wfumb2021.com.

Prof. Dr. Alina Popescu

Președinte executiv SRUMB (2020-2022) 